\title{
SMART
}

SMART

(Journal of English Language Teaching and Applied Linguistics)

Volume 7, No. 1, January 2021 Page. 15-20

p-ISSN: 2356-2048 e-ISSN: 2356-203x

\section{USING INFORMATION TRANSFER DIAGRAM ACTIVITY IN TEACHING LISTENING COMPREHENSION}

\author{
Aswadi Jaya \\ English Education Study Program, Universitas PGRI Palembang \\ Email Correspondance: aswadijaya@yahoo.com
}

\begin{abstract}
The reason to use the information transfer is because the students not only focus to listen but also to transfer the point what they hear. The main problem of this study was "Is it effective to teach listening by using information transfer diagram activity to the seventh grade students?" The method of the research used in this study was preexperimental method. Based on the result of the data analysis, it was found that teaching listening by using information transfer diagram activity to the seventh grade students.
\end{abstract}

Key words: Teaching, listening, information transfer diagram activity

\section{INTRODUCTION}

Now English is being important, especially for the collegians to help them in communication, science and also technology with other countries in the world easier. In Indonesia, English has been chosen as the first foreign language to be taught from the elementary school up to the college students. The students should master four language skills that should be owned by students, namely reading, listening, writing and speaking which relate to each other. According to Brown (2006), listening is a complex activity, and they can help students comprehend what they hear by activating their prior knowledge. Actually, Listening is the first stage to students to comprehend and improve their reading, writing, and speaking skill. In practice listening, the students acquire new vocabulary, pronunciation of word unconsciously.

Actually, listening as a receptive skill is one of difficult English skill. Many reasons why the students thought listening is difficult skill. However, Ningsih (2014) Listening is one of the skills that should be learned and mastered, but the students still have problem about it. Based on the writer's observation and also after the writer interviewed with the students of the state Madrasah Tsanawiyah Sakatiga of Indralaya about the process of teaching listening

\begin{tabular}{|ll|}
\hline OPEN 2 ACCESS & $\begin{array}{l}\text { Creation is distributed under the Creative Commons License Attribution } \\
\text { Share Alike 4.0 International Published in } \\
\text { https://ejournal.umpri.ac.id/index.php/smart/index }\end{array}$ \\
(c) $($ SMART Journal: Journal of English Language Teaching and Applied \\
Linguistics
\end{tabular}


comprehension in their classroom, the writer found the problems. Low motivation of the students, it made the students is not interested in listening. They got problem to listen well, especially when they heard English native speaker. Additionally, when the speaker spoke quickly, the students felt hard to identify words because of different stress, rhythm, and intonation pattern of native speaker. The students cannot get the point what speaker say, even they cannot remember what they heard. It made them bored to learn. Monotone lessons, of listening skill is always disregarded in teaching and learning process especially in junior high school, whereas listening has important role to master English. In teaching, the teachers just give listening material to students listen and write the answer correctly without knowing whether they understand the content of text. According to Wilson (2008), many of the differences between reading and listening illustrate just why listening is considered a difficult skill. The difficulties can be grouped into four general categories: characteristics of the message, the delivery, the listener and the environment. Jaya et al (2018) mention that in teaching English especially listening, teacher should apply an effective strategy, thus the students would be easily understanding the material.

In this problem, it was the great duty for English teacher to describe that listening in English is different from listening in mother tongue normally, and the teacher should be smart to find a suitable technique to teach listening. Talib (2014) to overcome the problem in teaching listening the writer will apply the strategy of information transfer diagram activity. The reason to used information transfer technique is because the students not only focus to listen but also to transfer the point what they hear in their group from loudspeaker or the teacher's sound. This technique made the students have the way to get information what they heard, where the students will try to transfer information what they heard in a diagram, picture, or graph. According to Wilson (2008), information transfer is the students complete a diagram or drawing based on what they hear. Here is a simple, low-level information transfer activity: the students each have an illustration of an empty plate. In pairs, they take turns to describe what they ate for lunch that day while their partner attempts to draw the food on the plate. According to a research result, conducted by Palmer (1982) It was mentioned that using transfer diagram activity was effective in teaching listening. thus, the 
Using...

writer conducted a research entitled "Teaching listening by using information transfer diagram activity to the seventh grade students of High School"

\section{RESEARCH METHOD}

In this research, the writer used a pre-experimental method (the one group pre-test and post-test). In the one-group pre-test-post-test design, a single group measured or observed not only after being exposed to a treatment of some sort, but also before (Frankel, Wallen and Hyun, 2012). Population is the larger group to which one hopes to apply the results. Population is all the subject of the research. The writer took the population from all of the seventh grade students of the state Madrasah Tsanawiyah Sakatiga of Indralaya in academic year of 2019/2020. There were consist of 9 classes and the total number of the population is 309 students. The test was used to collect data on subject's ability or knowledge. According to Brown (2004), a test is a method of measuring a person's ability, knowledge, or performance in a given domain. Test is any series of questions or exercise and other means which is used to measure competence, knowledge, intelligence, and ability or talent which is possess by individual or group.

In collecting data, the writer will use written test with test type multiple choice and true/false questions that consist of 20 multiple choices and 20 true false questions. Each multiple choice questions has four options and the test consists of 40 items. The students are asked to answer the questions after listen descriptive text from the teacher two or more times. In this research, the writer conducted two tests to the students. There are pre-test and posttest. Pre-test will give before the writer teaches the new material by using information transfer, the writer does the test relate in the materials to the students. state that an assessment instrument is to have a good quality if the instruments has or accomplishes two things, namely accuracy or validity and consistency or reliability. Meanwhile, Post-test will be given after the writer does experiment or gives treatment by using information transfer technique in teaching materials 


\section{FINDING AND DISCUSSION}

The findings of the study showed the result of pre-test, post-test, and matched t-test in doing the research. Based on the result, the writer found that teaching listening by using information transfer diagram activity to the seventh grade students of the state Madrasah Tsanawiyah Sakatiga of Indralaya was effective. Talib (2014) claims that teaching listening would be good if the teacher applies information transfer technique. Thus is is suggested that in doing the activity, the writer got progress the ability of students in studying listening of descriptive text by using information transfer diagram activity. It was because the students' score increased after doing treatment by using information transfer diagram activity.

According to Wilson (2008), information transfer: the students a complete diagram or drawing based on what they hear. Palmer (1982) mentions that information transfer diagram activity is effective, here is a simple, low-level information transfer activity: the students each have an illustration of an empty plate. Based on the finding of this study, the average score in post-test $\left(\overline{x_{1}}\right)$ was 7 and the average score in pre-test $\left(\overline{x_{2}}\right)$ was 5.38 . It showed that the ability of students' score in pretest was low ability level and after doing treatment the students' score in post-test was good enough level.

The students got progress the ability of students in studying listening of descriptive text by using information transfer diagram activity, where the students could focus and has known the technique to interpret the message of audio descriptive text. It indicated that the students get better skill through information transfer diagram activity and it motivates the students to explore their listening ability, where the average score in the post-test was higher than the average score in the pre-test. Meanwhile, the result of matched t-test was 8.53 exceeding 1.692 as its critical value at significant levels of $5 \%$ or .05 with df (33), for one tailed test. Based on the result of matched t-test, the null hypotheses $\left(\mathrm{H}_{\mathrm{o}}\right)$ was rejected because of $\mathrm{t}_{\text {obtained }}$ of 8.53 exceeded 1.692 and consequently the alternate hypothesis (Ha) was accepted or successful. It means that teaching listening by using information transfer diagram activity to the seventh grade students of the state Madrasah Tsanawiyah Sakatiga of Indralaya was significantly effective. 


\section{CONCLUSION}

Based on the finding of this study, the average score in post-test $\left(\overline{x_{1}}\right)$ was 7 and the average score in pre-test $\left(\overline{x_{2}}\right)$ was 5.38. It showed that the ability of students' score in pretest was low ability level and after doing treatment the students' score in post-test was good. Thus, the students got the progress in studying listening of descriptive text by using information transfer diagram activity, where the students could focus and has known the technique to interpret the message of audio descriptive text. Talib (2014) delivers that the students get better skill through information transfer diagram activity and it motivates the students to explore their listening ability, Information Transfer Diagram Activity in teaching listening descriptive text was helpful and made the students and the teacher interest in teaching and learning listening skill. Wilson (2008) states that transfer diagram would be effective in teaching listening. Thus, it could be seen through the result of the pre-test and post-test scores of the students' test. The post test score was higher than the result of pre-test score. The students' average scores in pre-test was 5.38. The students' highest scores in pretest was 7.75 and the students' lowest scores in pre-test was 3.0. After being taught listening descriptive text by using Information Transfer Diagram Activity, the students' average scores in the post-test increased to be 7.0. The highest score in post-test was 8.75 and the lowest score in post-test was 4.75 .

The result calculation in the matched t-test was 8.53. The t-obtained was higher than critical value (1.692). The writer concluded that the null hypothesis (Ho) was rejected and the alternative hypothesis (Ha) was accepted. Thus, the finding is relevant to the finding by Palmer (1982) that also claims that information transfer diagram activity is effective to be used in teaching listening. Finally it is concluded that teaching listening by using information transfer diagram activity was effective to the seventh grade students of the state Madrasah Tsanawiyah Sakatiga of Indralaya. 


\section{REFERENCES}

Arikunto, S. (1997). Prosedure Penelitian Suatu Pendekatan Praktek. Jakarta: Rineka Cipta.

Brown, H. D. (2000). Principles of Language Learning and Teaching. San Francisco: Wesley Longman, Inc.

Brown, S. (2006). Teaching Listening. New York: Cambridge University Press.

Chambers. \& Gregory. (2006). Teaching and Learning English Literature. London: SAGE Publications.

Etman,. Djodi. \& Nur, Z. (2009). Teaching Listening. Jakarta: Ministry of National Education.

Fraenkel, J.R. \& Norman, E. (2012). How to Design and Evaluate Research in Education. New York: Mc Graw-Hill, Inc.

Jaya, A., Hermansyah,. \& Mortini, A. (2018). The Effect of Crawford Series Teaching (CST) on the Students' Writing Achievement. ESTEEM Journal of English Study Program. $1(1)$.

Hatch, E., Hossein \& Farhady. (1982). Research Design and Statistics for Applied Linguistic. Cambridge: Newbury House Publishers.

Mursyid, M. P.W. (2012). Learning Descriptive Text. Pekalongan: SMPN 1 Karangdadap.

Ningsih, W (2014) . Teaching Listening by using "Filling Gap" to the eighth grade students of State Junior High School 35 of Palembang. Unpublished Thesis. PGRI University.

Palmer, D. M. (1982). Information Transfer for Listening and Reading . English Teaching Forum. Vol. 20, (1), 29-33, retrieved from http://downloadd/Information-transferPalmer-1982.htm (Access on $5^{\text {th }}$ January 2016).

Richard, J.C. (2006). Communicative Language Teaching Today. New York: Cambridge University Press.

Sudjana, N. (1989). Penilaian Hasil Proses Belajar Mengajar. Bandung: PT Remaja Rosdakarya.

Talib, R. (2014). The technique of information transfer for teaching English in EFL classroom based on authentic material. Yogyakarta: Gorontalo State University.

Wilson, J.J. (2008). How to Teach Listening. England: Pearson Education. 